\title{
NATURAL REASON AND GOD'S INFINITE POWER: DIVERSITY OF APPROACHES \\ IN THE LATE 13TH AND 14TH CENTURY COMMENTARIES ON AVERROES'S DE SUBSTANTIA ORBIS ${ }^{*}$
}

Keywords: De substantia orbis, Averroes, Averroism, Fernand of Spain, Maino de' Maineri, Philosophy in Medieval Paris, Philosophy in Medieval Erfurt

\section{Introduction}

The concise set of treaties called De substantia orbis is a very modest work with quite serious pretensions. As Averroes says, he intended to take up problems moved by Aristotle in the works that perished and did not come

* Łukasz Tomanek-PhD student at Faculty of Humanities at the University of Silesia in Katowice. He studied philosophy and classics at the University of Silesia in Katowice, and manuscript studies at the Pontifical Institute of Mediaeval Studies in Toronto. His research clusters around Latin reception of Averroes in 13th and 14th century philosophy of nature with special regard to commentaries on the De substantia orbis of Averroes.

Address for correspondence: University of Silesia in Katowice, Department of Philosophy, Bankowa 11,40-007 Katowice. E-mail: lukasz.tomanek@o365.us.edu.pl.

** This paper is a result of research financed from the grant of the Polish National Science Center (NCN) nr 2017/27/N/HS1/02528. 
to our times. ${ }^{1}$ As such, this work encompasses a summary of the whole interpretation of the Aristotelian corpus made by the Cordovan philosopher and can be therefore viewed as the abstract of the most important issues in the philosophy of nature, cosmology in particular. Among Latin schoolmen, De substantia orbis established itself along with Michael Scot's translation in the $2^{\text {nd }}$ half of the 13 th century. ${ }^{2}$ By the end of 13 th and the beginning of the 14th century, though, De substantia orbis had already been perceived as a supplement, annexus to Aristotle's De caelo, and as a text complementary to Metaphysics, Physics, De generatione and Meteorology, and by the end of the 13th century it became the material for academic lectures and philosophical exegesis. ${ }^{3}$ The commentaries on the De substantia orbis

${ }^{1}$ Averroes, De substantia orbis I (ed. Iuntina IX, f. 5vbK-L): "Declaratum est igitur ex hoc sermone quae est substantia caeli et hoc quod hic fuit dictum, enim quiddam eius invenitur probatum ab Aristotele in suis libris et quiddam sequitur ex suis dictis. Sed apparet ex verbis Aristotelis quod declaravit omnia ista in libris qui non pervenerunt ad nos. Vocetur ergo iste tractatus Sermo de substantia orbis. Dignior est enim hoc nomine quod intitulavit hoc titulo." The Giuntina edition of the De substantia orbis, to which I am referring here, is highly imperfect, so it made me use three additional manuscripts to compare them with the renaissance edition: Paris, Bibliothèque Nationale, lat. 6296; lat. 6506 ; lat. 15453 . On printed edition of the De substantia orbis critically compared with its manuscript transmission, see Licata, 2019.

2 On Latin version of the treatise compared to its Hebrew version, see Hyman, 1986 and esp. Licata, 2019; for an up-to-date list of known manuscripts containing Michael Scot's translation of the De substantia orbis, see Digital Averroes Research Environment (https://dare.uni-koeln.de/app/, last access: 5.01.2021).

${ }^{3} \mathrm{Cf}$. Fernandus Hispanus, Commentum in De substantia orbis, prooemium (Vatican, Biblioteca Apostolica, Vat. lat. 845, f. 272va): "Et licet Philosophus de istis entibus nobilibus, videlicet corporibus caelestibus et eorum motoribus, principalius in dicto libro Caeli et mundi inquirat quam in alio loco naturalis philosophiae ob difficultatem, tamen eorum in pluribus aliis locis sua librorum multa de ipsis interserit, ut patet 8 Physicorum, De generatione, 1 Metheororum et in pluribus locis suae Metaphysicae, praecipue in 12 . Et ideo sententia Aristotelis de natura caelestium corporum et eorum motoribus obscura necnon in quibusdam dubia esse videtur. Propter quod Averroes, commentator Aristotelis et eius philosophiae singularis emulator, quemdam libellum edidit quem De substantia orbis intitulavit in quo Aristotelis sententiam de natura caelestium corporum et eorum motorum necnon differentiam et convenientiam eorum ad generabilia et corruptibilia in substantia et in actionibus, tam ex parte corporum quam ex parte formarum breviter et optime explicavit, quaedam expressa ab Aristotele in diversis locis assumens, quaedam ex verborum eius intentione sillogizans." Here and in the following pages I am referring to manuscript Vat. lat. 845, which, according to my research, is the most reliable and consistent witness in the manuscript tradition of Fernand's commentary. The cited text has been critically 
cover what appear to be significant problems concerning the structure of transient beings compared with the structure of celestial bodies. The fragments of this opusculum, rendering the nature of the prime mover and the heavens, are especially significant in this regard. ${ }^{4}$ They refer to the subject matter that became the impulse towards setting the competition of natural reason and philosophy with faith and theology in investigating God and its attributes. In the kernel of this subject lies the question of how our natural faculties can acquire knowledge of God's power and divine causality by referring solely to the observation of local movement and non-experimental study of the substance of celestial spheres.

To illustrate the tension between natural cognition and conclusions of faith, I chose three commentaries on the De substantia orbis, two of which were written in Paris, one by Fernand of Spain in the last two decades of the 13th century and the other by Maino de' Maineri composed around $1315 .{ }^{5}$ The third commentary was anonymously composed in Erfurt

established by the author. For some of other manuscripts containing this commentary, see Weijers, 2003, p. 94; Iohannes de Ianduno, Quaestiones in Physicam, prologus (ed. Venetia, 1544, sine folio): "Considerandum est quod libris praenotatis in quibus traduntur partes scientiae naturalis annexi sunt quidam alii libelli Aristotelis et Averrois [...] liber autem Averrois De substantia orbis annexus est quodammodo libro Caeli et mundi quantum ad 1 et $2<$ librum> et aliqualiter 8 Physicorum."; Magninus de Maineriis, Quaestiones in De substantia orbis, principium (ed. Fioravanti, 2016, p. 223): "[I] tendo de corpore caelesti solum et de his quae ad eum (!) pertinent, de quo quamvis Aristoteles declaravit in primis duobus libris Caeli et mundi et in multis aliorum suorum librorum fecit mentionem, sicut in 2 De generatione et 8 Physicorum et 8 Metaphysicae et 12 , tamen nihilominus Averroes commentator egregius verborum Aristotelis voluit nobis tractatum de hoc facere, aggregans quae ab Aristotele dicta sunt diffuse in aliis, quaedam tamen eliciens ex verbis Aristotelis de ipso caelo quae Aristoteles non expressit. Et hunc librum volo ad praesens repetere ad meam informationem." I classicized and unified the Latin in the last fragment. The popularity of the De substantia orbis is also attested by its critical reception in works of Giles of Rome and Hervaeus Natalis: Aegidius Romanus, De materia caeli contra Averroistas (ed. Venetia, 1500, ff. 85r-90v); Hervaeus Natalis, De materia caeli (ed. Venetia, 1513, ff. 33rb-53va).

${ }^{4}$ See fragments discussed below on pp. 188-190.

${ }^{5}$ Both authors are often mentioned in the context of Latin Averroism and its development after condemnation in 1277 in late 13th and early 14th century Paris. For literature concerning Fernand of Spain, see n. 23. For literature concerning Maino de' Maineri, see n. 39. From the extensive literature dealing with the historical context of Parisian condemnations in 1270 and 1277 with their meaning, the following positions need to be listed: Bianchi, 1990; Bianchi, 1999; Bianchi, 2009; Libera, 1991, pp. 193-220; Putallaz, 
in the second half of the 14th century. I chose these commentaries due to the doctrinally different ways in which they tackle Averroes's treatise. For the sake of this article, I will label these two kinds of inquiry (1) an exegetical approach and (2) a critical approach on Averroes. The first two commentaries are examples of the former- they comment upon the De substantia orbis, adopting and consistently developing Averroes's solutions. In the third of the commentaries, although its author comments upon the De substantia orbis as an authoritative work, he does not follow Averroes's lead in choosing the answers but instead tends to perceive his work merely as a pretext for taking up philosophically important questions, disagreeing though with the solutions achieved by the Commentator. ${ }^{6}$

1995; Thijssen, 1998, pp. 40-56. For a general presentation of the intellectual climate and importance of Averroes at the Faculty of Arts in Paris at the beginning of the 14th century, see: Imbach, 1989, pp. 102-130; Riedlinger, 1967, pp. 12-67.

${ }^{6}$ In this paper, I deliberately refrain from labeling these two approaches as Averroistic or non-Averroistic, even though the first two commentaries are commonly known as representing Latin Averroism and heterodox ideas. I do not intend to measure the "degree" of Averroism in these authors, but - for purposes of this article-I prefer to see in their works the exegesis of authoritative work that the De substantia orbis was at the Faculty of Arts in Paris and later at the studium generale in Erfurt. The problem of Averroism in the case of these exegetes has already partially been covered by scholars (see below n. 21 and n. 38), yet the relationship between the author's Averroism and the fact of commenting directly on Averroes has not been studied yet. As will be seen below, commenting on Averroes-just like it was in the case of commenting on Aristotle or other authoritative works - did not always presuppose Averroistic inclinations or the clearly exegetic intentions of the author. Also, commenting upon the De substantia orbis, even with an explanatory scope, did not always mean uncritical sympathy for the Commentator. The example of a philosopher doctrinally far from being Averroist, yet at times following Averroes quite closely is Henry Totting de Oyta. In his early questions, written in Erfurt, on the De substantia orbis (Erfurt, Biblioteca Amploniana $2^{\circ} 297$, ff. 149ra-158rb), he is an exegete just as he is an exegete in his later paraphrases and detailed expositions of Aristotelian corpus. However, his commentary lacks questions on God's infinite power or divine causality — usually discussed even by authors critical to Averroes, like in the case of the anonymous Erfurt author presented below - which might mark Henry's unwillingness to discuss such controversial issues in the context of the De substantia orbis without discarding other valuable aspects of this treatise at the same time. Some clues as to the status of Averroes' work and the teaching practice might be found in John Aurifaber of Halberstadt, who taught in Erfurt and Halberstadt. In his long and complex Sophisma de dimensionibus (Leipzig, Universitatsbibliothek 1444, ff. 149va-152va), Aurifaber covers almost every issue examined in the De substantia orbis and cites Averroes' treatise in extenso multiple times. He explains 
The difference between these two approaches is readily apparent in the three questions lying in the intersection of philosophy with theology and causing several doctrinal controversies in the 13th and 14th centuries. These are (1) the question of the infinite power of the prime mover and (2) the question of efficient and final causality that comes with the prior. (3) The third issue I will analyze deals with the possibility of creation ex nihilo. Its conclusion is the consequence of the answers to the first two questions. To have a better insight into the character of the commentaries, I will present the outline of chosen aspects and excerpts from Averroes's works that were significant for Latin philosophers commenting on the De substantia orbis.

\section{Doctrinal Background}

One of the key concepts of Aristotelian physics is the axiom that everything that is in motion was previously moved by something else (omne motum ab alio movetur $).{ }^{7}$ For this reason, one of the most abstruse concepts in the medieval exegesis of Aristotle is the prime mover that is to be the origin of the eternal movement of the heavens and subcelestial world. Averroes puts the concept of prime mover in the middle of a discussion on the nature of the heavens and the whole subcelestial world, so in his commentaries and in the De substantia orbis it becomes one of the key concepts of the

that he intends to solve the problems discussed in accordance with Averroes' position because this way of proceeding provides an opportunity for better philosophical exercise (f. 150va): "Ne tamen propter hanc rationem quae valde longa est et tediosa aliquis recedat a via communi, ego intendo hic ponere duas solutiones forsan aliqualiter apparentes, fingens me in hoc de contraria opinione causa melioris exercitii, licet ex hoc aliqualiter praedictam videantur debilitare." All of these works require further research and are mentioned here only to present the complexity and ambiguity of the material and problems under scrutiny. For another example of such ambiguity, see n. 71. For further details on Henry Totting of Oyta, see Lorenz, 1989, pp. 185-200; Weijers, 2001, pp. 68-73. For the description of the manuscript Erfurt, Biblioteca Amploniana $2^{\circ}$ 297, see Schum, 1887, pp. 201-203, 815. For further details on John Aurifaber of Halberstadt, see: Lorenz, 1989, pp. 224-239; Pinborg, 1985, pp. 137-192; Weijers, 2001, pp. 119-120. For problems with establishing differentia specifica of Averroism, see Kuksewicz, 1997, pp. 93-96. For the "historiographical myth" of Latin Averroism, see: Fioravanti, 1966; Imbach, 1991; Libera, 1991, pp. 98-142; Marenbon, 2012; Piaia, 1985.

${ }^{7}$ For this principle, see Weisheipl, 1965. 
philosophy of nature. ${ }^{8}$ For 14 th century commentators, special attention was paid to the link between three causes only roughly sketched by Aristotle, i.e., (1) the last sphere of fixed stars - subiectum motus, or primum mobilewith its mover, the intelligence moving the spheres; (2) the lower celestial spheres with their movers; (3) the unmoved and unchanging prime mover, the first principle of the universe. All of these concepts were meticulously investigated in Averroes's long commentaries known in the Latin world from the early 13th century onwards. They were also briefly outlined in the De substantia orbis, where Averroes explains - often in various and slightly differing terms - the interaction between the prime mover and the celestial bodies.

According to the long commentary on the Physics VIII, the prime mover is not inhered in the matter but is subsistent, incorporeal, unmoved and does not have magnitude, so its action is infinite. ${ }^{9}$ The reason why it needs to be incorporeal is the following: If infinite power were applied to the body, it would follow that this body moved in no time (in instanti). On the other hand, if infinity were applied not to the body, it would be called neither infinite nor finite because these terms refer only to body and magnitude. Thus, no concept of finitude or infinity can be applied to it, since they refer only to bodies. ${ }^{10}$

${ }^{8}$ For further details, see: Jung-Palczewska, 1997, pp. 47-49; Maier, 1955, pp. $227-$ 234.

${ }^{9}$ Averroes, Commentum in Phys., lib. VIII, com. 78 (ed. Iuntina IV, f. 423vaI): "Motor primus non est in materia, sed subsistens per se."; Averroes, Commentum in Phys., lib. VIII, com. 86 (ed. Iuntina IV, f. 433vbK): "Concludit quod primus motor de quo declaratum est ipsum non moveri non habet corpus, id est non habet formam in materia [...] non potest habere magnitudinem, id est cum iam ostendimus quod omnis corporis finiti actio est finita et similiter omnis virtus in corporeet quod primi motoris actio est infinit, manifestum est quod primus motor non habet magnitudinem omnino."

${ }^{10}$ Averroes, Commentum in Phys., lib. VIII, com. 79 (ed. Iuntina IV, f. 427rbE-F): "Finitum et infinitum solum de corporibus dici possunt et sic sola actio istorum dicetur infinita. [...] Si vero illam posueris in corpore, tunc non dicetur finitum aut infinitum eo quod non est in corpore. [...] Unde, si dixerimus potentias esse in corporibus, tunc actio earum erit proportionalis, scilicet quod proportio potentiae motivae ad potentiam motivam est sicut proportio velocitatis motus ad velocitatem. Existentibus autem non in corpore non est proportio, cum proportio solius est magnitudinis ad magnitudinem." 
In his long commentary on the Metaphysics,${ }^{11}$ Averroes takes up the question of the prime mover's nature, distinguishing three kinds of power: power in substance (in substantia), in alteration (in alteratione) and in the local movement (in ubi). The notion of infinite and finite might only be applied to the third one since the power Averroes is referring to is the force of movement. ${ }^{12}$ This movement, he explains in the long commentary on the Metaphysics XII, has its source in two different movers: the prime mover, which is infinite and moves with finite motion, and the second mover, also identified with the intelligence of the first sphere, i.e., the sphere of the fixed stars. The prime mover does not move as an efficient cause, but as a finite cause, so, as such, it does not perform any action. Yet, the intelligence of the first heaven moves the lower spheres as an efficient cause in consequence of thinking and desiring the first principle, which is the most desirable principle of the universe every other sphere is heading towards. ${ }^{13}$

According to the long commentary on the De caelo II, due to proximity of the first principle, the intelligence of the first sphere-which is

11 For further details on Averroes's concept of the prime mover and cosmology in his commentary on the Metaphysics, see Genequand, 1986, pp. 33-48, 54-55.

12 Averroes, Commentum in Metaphys., lib. XII, com. 41 (ed. Iuntina VIII, f. 324raCbD): "Est enim potentia in substantia, in alteratione et in ubi. [...] Corpus caeleste non habet potentiam nisi tantum in ubi. Si igitur potentia qua movetur hoc motu aeterno fuerit in eo, aut est finita aut infinita. [...] Sed non consequitur ex hoc quod omne corpus habeat omnem potentiam quia corpus caeleste non habet potentiam nisi tantum in ubi."

${ }^{13}$ Averroes, Commentum in Metaphys., lib. XII, com. 41 (ed. Iuntina VIII, f. 324rbE-F): "Iste motus componitur ut declaratum est ex duobus motoribus quorum unum est finitae motionis et est anima existens in eo; et alter est infinitae motionis, et est potentia, quare non est in materia. Secundum igitur quod movetur a potentia finita movetur in tempore, cum dicere finitatem est habere proportionem terminatam ad motam rem et in sua substantia est aeterna."; Averroes, Commentum in Metaphys., lib. XII, com. 36 (ed. Iuntina VIII, f. 319raC-bD): "[S] motor corporum caelestium est magis bonus omnibus, necesse est, ut sit desideratus magis bonis omnibus. Et intendebat $<$ Aristoteles $>$, cum dicit et non existimatur, quia desideramus distinguere inter desiderium intellectus et sensus. In quo enim appetitus sensuum non dominatur super intellectum, reputatur desideratum esse bonum, quia est desiderabile. Et omnia ista dicit ad declarandum quod corpora caelestia, cum habent appetitum propter intellectum. Intellectus autem maius bonum ipso appetit, contingit necessario quod corpora caelestia appetunt in hoc motu aliquid magis bonum ipsis. Et cum illa sunt nobilissima corpora sensibilium et meliora, necesse est, ut illud bonum quod appetunt sit nobilissimum entium et maxime quod appetit totum caelum in motu diurno." 
also the second mover-is moved directly by the unmoved prime mover as an end of the movement and the intelligible object of desire. Thus, the second mover moves the heavens with a constant finite force, proportional to the force the third and every subsequent sphere can absorb in their eternal movement. ${ }^{14}$ Also, the proximity to the first mover determines the number of actions the spheres perform, i.e., the first sphere and its mover performs only one action to attain the goodness of the first principle, the next sphere needs two actions, and so every subsequent mover needs more action due to the distance from the goodness they are trying to achieve. ${ }^{15}$

In the De substantia orbis ${ }^{16}$ Averroes addresses the issue of the correct understanding of the term "infinity" once applied to the prime mover's power, tackling it in a slightly different way. Among the distinctions concerning the

14 Averroes, Commentum in De caelo, lib. II, com. 38 (ed. Carmody, 2003, pp. 342-342, 11. 68-70, 78-82, 90-94, 98-102): "Et ob hoc quidem necesse est ut omnis motus naturalis et voluntarius habeat velocitatem terminatam, quia omnis motus habet motorem terminatum. [...] Et si potentiae eorum essent infinitae in vigore movendi, non esset proportio inter motorem et rem motam; et si hoc esset, non esset differentia inter eos, neque esset illic multitudo omnino, verbi gratia quia motor orbis Saturni et motor totius moveret tempore infinito. [...] Si ceteri orbes habuissent ex multitudine stellarum quod habet orbis stellatus, tunc motor eorum non posset movere eos in velocitate quam modo habent. [...] Potentiae moventium sunt terminatae proportionis ad corpora mota. [...] Causa in terminatione proportionum quae sunt inter potentias motorum et rerum motarum ab eis est diversitas formarum. [...] Haec infinitas sit communis formis quae sunt in materia et formis quae non sunt in materia."

15 Averroes, Commentum in De caelo, lib. II, com. 62 (ed. Carmody, 2003, p. 393, 11. 34-40): "[P]rimum caelum, quod movetur motu diurno quod est nobilius eorum que sunt illius generis, necesse est ut acquirat nobilitatem que est in illo genere una actione, et quod illud quod est valde remotum ab eo aut acquiret ipsam magna operatione aut omnino non acquiret eam magna operatione neque parva, sed acquiret nobilitatem de qua habet naturam ut acquirat, et ea que sunt media acquirent operatione media." Averroes, Commentum in De caelo, lib. II, com. 63 (ed. Carmody, 2003, pp. 395-396, 11. 46-54): "[I] am enim declaravimus illic quod additio potentiae motoris super potentiam moti non est infinita nisi in tempore et in aeternitate motionis, non in velocitate neque in multitudine motuum neque in magnitudine corporum, quoniam si esset in magnitudine corporum et motuum multitudine et velocitate motuum, esset possibile invenire motum non in tempore et corpus motum infinitum quod est impossibile; et quod est possibile ex istis non est nisi motionem esse infinitam, secundum quod dicitur quod potentiae istorum motorum sunt infinitae."

16 For doctrinal importance of the treatise and its impact on the Latin world, see Lerner, 1996, pp. 139-164. 
nature of the prime mover and its attributes, the twofold notion of infinity plays a key role, namely infinity as a force of infinite action and passion in time, but finite in itself that is finite in velocity and force; and infinity as a force of infinite action and passion in itself. ${ }^{17}$ In the former meaning, infinity is understood as the ability to cause movement of infinite duration but of a finite force. In the latter, it is the ability to cause movement which is infinite in its velocity and force. Averroes rejects the assumption that an infinite action of the like might be performed among corporeal bodies, so he states that the prime mover is infinite in duration - it causes the movement to last eternally - yet it is finite in its power since he cannot interact with infinite force on something which is of finite nature. ${ }^{18}$ In the De substantia orbis Averroes also develops a concept present later in his long commentaries, i.e., that celestial spheres with their intelligences have appetitive virtues that are the very reason they are leaning towards something desirable. And since the most desirable object is the prime mover, they are leaning towards it as to the final cause, thus continuing and preserving the movement of the inferior parts of the universe. ${ }^{19}$ As such, the celestial bodies as separate substances are also both final and efficient causes. As the former, they are

17 Averroes, De substantia orbis III (ed. Iuntina IX, f. 9rbF-vaG): "Et ad hoc dicamus breviter quod infinitum dicitur duobus modis quorum unus est virtus infinitae actionis et passionis in tempore et est finita in se, scilicet in velocitate et vigore; secundus est virtus infinitae actionis aut passionis in se."

${ }^{18}$ Averroes, De substantia orbis III (ed. Iuntina IX, f. 9vaH-I): "Infinitum igitur esse in vigore cuius causa est corpus secundum quod est corpus impossibile est in corporibus sive caelestibus sive aliis. Infinitum vero in tempore esse est necesse in corporibus caelestibus ex diversitate motoris et moti in eis a corporibus generabilibus et corruptibilibus. Et est impossibile in corporibus generabilibus et corruptibilibus, quia virtutes eorum motivae sunt motivae materiales et corpora sua quae moventur ab eis componuntur ex materia et forma."

19 Averroes, De substantia orbis IV (ed. Iuntina IX, f. 10rbF): "Et cum consideravit de istis virtutibus, declaratum fuit ei ipsam esse virtutem appetitivam de virtutibus animae tantum. Et cum consideravit in virtutibus appetitivis caelestibus vidit eas moveri ad appetibile nobilius ipsis. Et cum consideravit de virtutibus appetitivis caelestibus, invenit eas esse finitarum potentiarum. Et cum consideravit in continuatione motus eorum, fuit declaratum quod causa continuationis non est ista qua movetur, sed illud quod largitur eis continuationem est aliud appetibile." 
the ends for lower spheres with their intelligences, and as the latter, they are direct causes of movement for subsequent lower spheres. ${ }^{20}$

In summary, according to Averroes's view, the Aristotelian prime mover-identified by Arabic, Jewish and Christian philosophers as the God of religion - moves as a final cause, the most desirable principle, unmoved and unchanging, desired as an end by the whole of heaven. Yet these concepts may, to some extent, cause confusion, and some questions are still to be raised: what does it mean that the prime mover is neither finite nor infinite but moves with finite power? Is the prime mover merely a final cause or also, at least to some extent, an efficient cause? Since it is only a final cause, it does not actively interact with the universe he created. Furthermore, if it does not have infinite force or efficient causality, then God's ability to freely create various effects - including the creation of the world — can be questioned and challenged.

\section{Fernand of Spain on the De substantia orbis}

Fernand of Spain (Fernandus Hispanus) was a university master at the Faculty of Arts in Paris in the last two decades of the 13th and, probably, the first decade of the 14th centuries. He is known as the author of vast commentaries on the Metaphysics or the Economics, and he also composed a treatise, De specie intelligibili. Moreover, Fernand authored the commentary on the De substantia orbis that was traditionally ascribed to John of Jandun. In his works, he adopted some ideas characteristic of the Averroistic current of the late 13th and early 14th centuries, of which his commentary on the De substantia orbis appears to be a good example. ${ }^{21}$ In Fernand's commentary, there are several quaestiones that undertake

${ }^{20}$ Averroes, De substantia orbis I (ed. Iuntina IX, f. 5vaG): "Nihil est in corporibus caelestibus quo forma qua est motus differat ab ea ad quam est motus, immo sunt eadem forma et non differunt nisi dispositione."

${ }^{21}$ I undertake a detailed discussion on this attribution in my $\mathrm{PhD}$ thesis, so I omit further explanations on this subject. On general and rather scarce details about Fernand's biography, see: Weijers, 1996, pp. 87-89; Zimmermann, 1968; Zimmermann, 1994, pp. 214-216. Although there is no single article devoted to difficult and dubious attribution of this commentary to John of Jandun, there are, however, several articles where the problem was mentioned, see: Etzkorn, 1981, pp. 120-122; Hoffmann, 2001; 
this issue and are accompanied by a heavily detailed expositio textus. To keep the article compact, I will focus solely on question X, Utrum in separatis a materia efficiens et finis differant vel sint idem; and question XII, Utrum primus motor vel primum principium sit infinitum in vigore. ${ }^{22}$

In his commentary on the De substantia orbis Fernand claims that many schoolmen perceive Aristotle, and the Commentator in particular, as remaining in opposition to the Catholic faith. ${ }^{23}$ Many of them think that the Commentator states the first principle is limited in its power because the prime mover sets the heavens in motion with a limited velocity. ${ }^{24}$ The fundamental problem underlying this misunderstanding, says Fernand, is the obscure concept of the prime mover and its nature that can be found in Averroes's long commentary on the Physics VIII. ${ }^{25}$ Averroes writes in various places about separated movers (motores separati) as causing the eternal movement (motus perpetuus) and having a finite power (vigor determinatus). Fernand-after

Zimmermann, 1994, pp. 215-216; Zimmermann, 1995. On the doctrinal content of the commentary as attributed to John of Jandun, see: Lamy, 2012a; Maurer, 1990, pp. 283285. On the debate concerning Fernand's Averroism, see: Galle, Guldentops, 2004, pp. 51-55; Kuksewicz, 1977, pp. 187-192; Van Steenberghen, 1974, pp. 548-550; Zimmermann, 1968.

22 In Fernand's commentary, there is also question XIII, Utrum intelligentiae dependeant a primo principio in ratione causae efficientis vel solum finis (Vatican, Biblioteca Apostolica, Vat. lat. 845, ff. 299va-300rb) which takes up the discussed problems in a similar manner. For the purposes of this short presentation though these two questions provide enough material for analysis.

${ }^{23}$ Fernandus Hispanus, Commentum in De substantia orbis, q. XII, Utrum primus motor vel primum principium sit infinitum in vigore (Vatican, Biblioteca Apostolica, Vat. lat. 845, f. 294va): "De ista quaestione credunt multi magni viri in philosophia opinionem Philosophi et praecipue Commentatoris veritati fidei catholicae adversari."

${ }^{24}$ Fernandus Hispanus, Commentum in De substantia orbis, q. XII, Utrum primus motor vel primum principium sit infinitum in vigore (Vatican, Biblioteca Apostolica, Vat. lat. 845, f. 294vb): "Et sic ex omnibus istis videtur esse de intentione Commentatoris, quod primum principium est finitum in vigore, quia ipsum est primus motor qui movet primum mobile in velocitate terminata."

${ }^{25}$ Fernandus Hispanus, Commentum in De substantia orbis, q. XII, Utrum primus motor vel primum principium sit infinitum in vigore (Vatican, Biblioteca Apostolica, Vat. lat. 845, f. 294vb): "Sed opinio Commentatoris et Philosophi per consequens latet sic opinantes, ut statim apparebit. Causa autem huius latentiae, ut existimo, est duplex. Una est defectus termini demonstrationum 8 Physicorum quae communiter deficiunt de commento Averrois in quarum ultima istam quaestionem movet et determinat in propria forma. Et quia communiter non habetur, ideo communiter eius intentio ignoratur." 
reproaching some unnamed authors for the frequent error of transferring Averroes's investigations of the separated movers to the investigations of the prime mover-stresses that Averroes's solution is the following: the prime mover (motor separatus), is a power utterly separated that remains incorporeal (potentia omnino separata), while the other movers, however, are only partially separated and partially connected with matter (quandoque separati, also called motores appropriati). ${ }^{26}$ Furthermore, it is unreasonable to accept infinite power in bodies (in corpore), for, if it were in bodies, the movement would occur in no time (in instanti), which is impossible since the movement is being caused within time. Also, the occurrence of infinite action in the body would result in contradiction, i.e., the existence of infinite power inhered in magnitude. Yet, the occurrence of infinite power not in the body (non in corpore) is also impossible, for the finite and infinite can occur only in relation to bodies and magnitude. Therefore, to avoid contradiction, the prime mover itself cannot be considered - properly speaking - by means of the finite-infinite categories, for it remains beyond the matter and moves with a finite force. It also cannot influence with infinite power the celestial body, i.e., the heavens and its movers, partially connected with bodies. ${ }^{27}$

${ }^{26}$ Fernandus Hispanus, Commentum in De substantia orbis, q. XII, Utrum primus motor vel primum principium sit infinitum in vigore (Vatican, Biblioteca Apostolica, Vat. lat. 845, f. 294vb): “Altera est, quia_cum Aristoteles in 8 Physicorum probat motum perpetuum causari a motore separato qui non est corpus nec virtus in corpore - intelligit istum motorem esse primum principium, et ideo cum in 2 Caeli et mundi Commentator dicat quod omnes motores separati sunt vigoris determinati, creditur hoc extendi ad primum motorem omnino separatum, non advertens quod in eodem 8 et in 2 Caeli et mundi et in 12 Metaphysicae vocat primum principium potentiam omnino separatam quae non est in corpore, motores vero appropriatos vocat quandoque separatos, quandoque vero potentias in corporibus diversis respectibus. [...] Vocat ergo potentiam infinitam quae non est in materia primum principium et dicit ipsum non esse in materia respectu motorum approptiatorum, quasi innuens motores appropriatos esse in corporibus."

27 Fernandus Hispanus, Commentum in De substantia orbis, q. XII, Utrum primus motor vel primum principium sit infinitum in vigore (Vatican, Biblioteca Apostolica, Vat. lat. 845, f. 295ra): “Circa hoc movet quaestionem, scilicet quare sequitur quod, si potentia infinita esset in corpore, motus fierit in non tempore et non sequitur istud, si potentia sit non in corpore, ex quo enim potentia est infinita et movet sive illa potentia infinita sit in corpore sive non, videtur quod deberet esse motus in instanti. Et respondens dicit, quod si aliqua actio infinita sit alicuius corporis vel virtutis in corpore, sequitur virtutem illam esse infinitam, sed si actio fuerit alicuius virtutis non in corpore, tunc illa virtus secundum id quod est corporis non potest dici finita nec infinita. Cuius ratio est, 
Given that the prime mover moves with finite force, the continuity and eternity of movement need to be explained. The celestial spheres, says Fernand after Averroes, have no potency to be corrupted, and their movement has continuous existence. However, the celestial body has matter, although in equivocal meaning compared to the matter of transient beings. Thus, the celestial body, although eternal in its substance, does not have continuity from itself, since it is virtually possible for them to move or not move eternally, in other words, their movement is not necessary, it has the potency to stop moving at some point (in caelo non est possibilitas nisi ut quiescat). The reason that it does not cease to move must be then external to it, so it must be caused by a mover that does not have potentiality at all — neither essentially, nor accidentally — and this mover is the first principle of the world, the prime mover having infinite power in duration. ${ }^{28}$

In order to clarify the relation between God and the created world, i.e., to specify the causal relation between them, Fernand of Spain introduces the concept of two movers: the first and simple mover, i.e., God, being utterly separated from matter (motor separatus) that acts indirectly (mediatum) as a final cause (finis) through the second mover (motor appropriatus), that is

quia finitum et infinitum solum de corporibus et magnitutidinibus dici possunt, ut apparet 1 Physicorum, quia 'finitum et infinitum quantitati congruunt'."

${ }^{28}$ Fernandus Hispanus, Commentum in De substantia orbis, q. XII, Utrum primus motor vel primum principium sit infinitum in vigore (Vatican, Biblioteca Apostolica, Vat. lat. 845, f. 295va): "Intelligendum tamen quod primum principium dicitur infinitum in duratione, licet non dicatur infinitum in vigore. Cuius ratio est, quia, sicut dicit Commentator in loco praeallegato 12 Metaphysicae, "in corpore caelesti non est potentia, ut corrumpatur, quia non habet contrarium, et ideo est permanens per suam substantiam, motus autem eius non est permanens per suam essentiam, cum habeat contrarium, scilicet ipsam quietem", et ideo potest corrumpi. Ad hoc igitur quod motus caeli permaneat aeternaliter "oportet ponere aliquam potentiam permanentem aeternaliter sine possibilitate corruptionis et permutationis, quia in caelo non est possibilitas nisi ut quiescat. Et quia probatum est esse impossibile caelum quiescere [...], igitur necesse est, ut ista permanentia motus sit propter motorem in quo nulla est potentia omnino nec essentialiter nec accidentaliter et tale non est in materia omnino". Et sic permanentia motus et continuitas est a primo principio et ideo subdit Commentator circa finem eiusdem partis quod "potentiae moventes corpora caelestia, scilicet motores appropriati, possibile est, ut semper moveant et ut semper non moveant. Possunt enim non semper movere, si posuerimus illud ad quod moventur, scilicet primum motorem esse receptibilem transmutationis cuiuscumque modi. Possunt autem semper movere, quando illud ad quod movent fuerit non transmutabile aliquo modo transmutationis." 
intelligences, or more precisely, the intelligence of the last sphere, which affects the world directly (immediatum), i.e., as an efficient cause. ${ }^{29}$ The prime mover as motor separatus does not move the heavens, i.e., primum mobile, directly, but indirectly through the second mover that interacts with the subject of the movement, i.e., the first sphere. The movement of the heavens lasts eternally due to the action of God as the final cause, the first principle, which is immovable and unchanging. These two attributes are also the very reason why it does not act as an efficient cause that affects the world by direct action. ${ }^{30}$ Thus, all activity that occurs in the world is caused not directly by God, referred to above as motor separatus and object of love, amatum, but by the connected mover, i.e., motor coniunctus, also referred

29 Fernandus Hispanus, Commentum in De substantia orbis, q. X, Utrum in separatis a materia efficiens et finis differant vel sint idem (Vatican, Biblioteca Apostolica, Vat. lat. 845, f. 289rb; 290ra): "Ad quaestionem dicatur quod in separatis duplex est movens, scilicet movens mediatum quod est simpliciter primum, scilicet deus ipse; et movens immediatum ut sunt intelligentiae. [...] Quare apparet primum movere solum in ratione finis, dicit etiam in eodem 12 quod "non est idem, quod motor primi mobilis intelligit de primo principio, cum eo quod de ipso intelligit motor Saturni”. Supra etiam in isto libello dicit quod formae corporum caelestium et maxime corporis ultimi, scilicet primi caeli, est anima appetitiva et intellectiva, et si primum caelum habeat animam, quae est motor appropriatus praeter ipsum primum, sequitur quod primum non movet nisi ut finis et ubique intentio sua sonat istud." Fernandus Hispanus, Commentum in De substantia orbis, q. XII, Utrum primus motor vel primum principium sit infinitum in vigore (Vatican, Biblioteca Apostolica, Vat. lat. 845, f. 295va-b): "Ideo semper eodem modo intelligitur $\mathrm{ab}$ animabus caelestibus et desideratur. Et quia semper idem eodem modo intelligunt et desiderant, ideo semper eodem modo movent, quia igitur permanentia primi est causa permanentiae continuitatis motus, ideo permanentia primi et duratio habet attributionem ad motum qui est de genere quantorum vel consequitur quantum. Et ideo ut sic competit sibi infinitas, et ideo dicitur infinitus in duratione, sed quia vigor eius non habet attributionem ad motum nec ad aliud, quia non movet nisi ut finis, ideo non movet per vigorem, et ideo sibi non competit infinitas vigoris."

${ }^{30}$ Fernandus Hispanus, Commentum in De substantia orbis, q. X, Utrum in separatis a materia efficiens et finis differant vel sint idem (Vatican, Biblioteca Apostolica, Vat. lat. 845, f. 289va): "Secundo tamen dico quod primum movens quod est movens mediatum movet in ratione finis tantum et non in ratione efficientis. Et videtur de intentione Philosophi et Commentatoris expresse, quia ut Philosophus dicit 2 Caeli et mundi: Quod enim est nobile et perfectum simpliciter, non indiget actione extrinseca in acquisitione nobilitatis, quia nec indiget assimilari alicui ex quo simpliciter est primum et a se est omnis nobilitas et omnis perfectio; sed primum principium est huiusmodi; quare ipse non movet effective." 
to as amans, which affects the world directly and with a single action, ${ }^{31}$ a consequence of desiring the first principle. ${ }^{32}$ The division into two movers enables us to grasp how the prime mover, transcending finite-infinite categories, moves the world with finite force: it moves as an end (finis) to which all the universe leans towards, thus setting the spheres and the whole world into movement with constant force. Fernand illustrates this dependence with an example borrowed from Averroes's long commentary on the Metaphysics XII: a healthy person does not go for a walk to gain health but to maintain it. In this sense, the first intelligence does not desire to be like the prime mover, but to maintain the likeness it already has. ${ }^{33}$ Thus the connection between the three main causes of the world discussed in the De substantia orbis and later in long commentaries ${ }^{34}$ appears to be as follows: (1) the prime mover, as a final cause infinite in duration, is the object of desire of (2) the connected mover that - as a consequence of its desire and intellection of the first principle - sets with constant and finite power (3) the entire world, i.e., the heavens with the lower spheres, in eternal motion.

31 On the movement and actions of the spheres, see Averroes' position on p. 187 and Maino's application of this solution on pp. 197-199.

32 Fernandus Hispanus, Commentum in De substantia orbis, q. X, Utrum in separatis a materia efficiens et finis differant vel sint idem (Vatican, Biblioteca Apostolica, Vat. lat. 845 , f. 289vb): "Dicit enim quod primum movet in ratione amati et desiderati, et postquam ostendit ibi Philosophus conditiones primi moventis extrinseci, inquirit quid est principium huius motus in ipso motore et dicit quod hoc est intelligentia. Quare apparet quod ipse vult praeter primum sit alius motor coniunctus qui movet effective. Et Commentator ibidem dicit quod "primum caelum movetur ab unico motore, scilicet primo, secundum desiderium, ut assimiletur ei secundum suum posse, sicut amans movetur, ut assimiletur suo amato, alii vero orbes moventur secundum desiderium ad motum primi”, ut dicit. Ex quo apparet quod primum non movet nisi ut finis."

${ }^{33}$ Fernandus Hispanus, Commentum in De substantia orbis, q. X, Utrum in separatis a materia efficiens et finis differant vel sint idem (Vatican, Biblioteca Apostolica, Vat. lat. 845, f. 290rb): "Ad primam dicatur quod intelligentiae moventur per illud quod intelligunt de primo, non ut acquirant similitudinem eius quam non habent, sed ut similitudinem eius quam habent conservent per motum et causalitatem, ut sanus deambulat non ut sanitatem acquirat, sed ut sanitatem quam habet conservet, ut Commentator dicit 12 Metaphysicae, modo quia intelligentiae non intelligunt per species acquisitas ex sensibus, sed per essentias suas et ipsum primum est intellectus abstractus, sicut ipse licet multo perfectior."

${ }^{34}$ See above pp. 185-190. 
Fernand concludes that what he presents is the Philosopher's and the Commentator's intention, and it should be clear to anyone who diligently deliberates on this matter. He also states that Averroes's solution does contradict the Catholic faith even though, according to theologians, God has infinite power, not being limited by any relation whatsoever. ${ }^{35}$ However, regardless of how convincing the Spanish commentator wants to be when he justifies the lack of contradiction between faith and reason in this matter, Fernand's constant negation of divine efficient causality leads to further doctrinal consequences that are fairly unorthodox in their meaning. The first and foremost is denying the possibility of the creation of the world ex nihilo. As Fernand says, the prime mover does not create ex infinita distantia, i.e., ex nihilo - this solution is excluded alongside the choice of philosophical argument. ${ }^{36}$ Furthermore, discarding creatio ex nihilo is the consequence of the recognition of the prime mover not as causa efficiens, but as causa finalis only. As a result of these assumptions, it follows that the prime mover as a causa finalis is not an agent cause, changing, moving and affecting the world directly. It is rather the distant end that the whole world is heading for. As such the prime mover tends to preserve the existence of beings and make them more perfect, simultaneously maintaining the continuity and eternity of movement. It is impossible for the prime mover as a final cause to cause the transition from non-esse to esse.

35 Fernandus Hispanus, Commentum in De substantia orbis, q. XII, Utrum primus motor vel primum principium sit infinitum in vigore (Vatican, Biblioteca Apostolica, Vat. lat. 845, f. 296vb): "Hoc videtur esse intentio Philosophi et expresse Commentatoris circa istam quaestionem, nec est repugnantia in verbis Commentatoris diligenter consideranti, licet hoc aliqui credant. Et ista opinio non discordat realiter a veritate fidei, licet verba theologorum dicunt primum principium esse infinitum in vigore, quia intelligunt ipsum non limitatum nec proportionatum alicui, sed extra proportionem alicuius alterius virtutis."

${ }^{36}$ Fernandus Hispanus, Commentum in De substantia orbis, q. X, Utrum in separatis a materia efficiens et finis differant vel sint idem (Vatican, Biblioteca Apostolica, Vat. lat. 845, f. 296ra): “Ad aliam, cum dicitur: 'Illud quod causat ex infinita distantia' etc. Concedatur maior et si minor esset concessa, concluderet ratio necessario, sed philosophi negarent minorem et probationem eius, quia, sicut apparet ex 1 Physicorum, 'communis conceptio omnium philosophorum fuit quod ex nihilo nihil fit'." 


\section{Maino de' Maineri on the De substantia orbis}

The immediate relation between the question of the infinity of the world and the power of God can be found in the commentary on the De substantia orbis composed ca. 1315 by Maino de' Maineri (Magninus de Maineriis). He was active at the Parisian Faculty of Arts in the second decade of the 14th century. At the time, he also commented upon the De anima. He is recognized as socius of John of Jandun - he took part in several disputes with him and other Parisian masters. ${ }^{37}$ His commentary discusses the problem of the infinite power of God in the question that focuses on the creation of the world from nothing, i.e., question VI, Utrum ex nihilo possit aliquid fieri. ${ }^{38}$

At the beginning of divisio textus Maino starts where Fernand's investigations end. Maino presents two popular views on creation: first, an opinion, attributed to Avicenna, discussing the possibility of the world's creation ex aeterno; and second, a religious view that the world was created de novo, i.e., ex nihilo. ${ }^{39}$ Maino devotes much attention to disproving the first view, yet he comments on the second with only one sentence and claims it not to be questioned, for God's power is no doubt able to create anything out of nothing. ${ }^{40}$ Then, he declares he will discuss the question according

${ }^{37}$ For further details on his life, work and activity in Paris, see: Ermatinger, 1959; Ermatinger, 1976; Fioravanti, 2016; Fioravanti, 2017; Kuksewicz, 1999; Kuksewicz, 2006; Weijers, 2005.

38 The commentary has been preserved in a single manuscript: Firenze, Biblioteca Nazionale, Conv. Soppr. J III 6, ff. 89ra-108va. For further details on the manuscript, see: Kristeller, 1977, pp. 162-163; Punta, Luna, 1989, pp. 122-132. On the infinity of God's power, see also (omitted here) a short discussion that Maino included in his Quaestiones in De anima III, q. 14, Utrum noster intellectus coniunctus magnitudini intelligat separata a materia (Bologna, Biblioteca Universitaria, 1625, f. 166rb). For further details on Maino's opinions, see Kuksewicz, 2006, pp. 352-353. The critical edition of this commentary has been prepared by Iacopo Costa and Jean-Baptiste Brenet. For the manuscript and its content, see: Xiberta, 1924, pp. 162-166; Xiberta, 1932, pp. 48-49.

39 Magninus de Maineriis, Quaestiones in De substantia orbis, q. VI, Utrum ex nihilo possit aliquid fieri (Firenze, Biblioteca Nazionale, Conv. Soppr. J III 6, f. 96va): "Quidam autem philosophorum dixerunt hinc fuisse ab aeterno, ut imponitur Avicennae, et quidam legis nostrae ponunt hoc fuisse possibile. Alii dicunt quod illa creatio fuit de novo et non ab aeterno."

${ }^{40}$ Magninus de Maineriis, Quaestiones in De substantia orbis, q. VI, Utrum ex nihilo possit aliquid fieri (Firenze, Biblioteca Nazionale, Conv. Soppr. J III 6, f. 96va): "Sed illi qui ponunt creationem fuisse ab aeterno sine posse fuisse habent difficile contra se, 
to a third view, that is Aristotle's and the Commentator's. ${ }^{41}$ During the very long and complex discussion concerning the different aspects of creation and the substantial composition of form and matter, Maino argues for the possibility of creation only from a preexisting subiectum, i.e., matter. ${ }^{42}$ This decision is based on the same grounds on which Maino subsequently argues in the same question, that the prime principle has no infinite power because it is not possible to gain knowledge of God's power based solely on empirical data, i.e., the observation of local movement. ${ }^{43}$ This claim marks Maino's acceptance of the boundaries within which our natural faculties are restrained when investigating realms that are beyond human perception. Having acknowledged these cognitive limitations, Maino proceeds to reassess divine causality and God's power-problems strictly connected

quoniam hic videtur implicare contradictionem." Magninus de Maineriis, Quaestiones in De substantia orbis, q. VI, Utrum ex nihilo possit aliquid fieri (Firenze, Biblioteca Nazionale, Conv. Soppr. J III 6, f. 97ra): “Opinionem legis nostrae quae ponit quod ex nihilo fiat aliquid modo supradicto tam in substantiis quam in accidentibus non intendo improbare, quoniam virtus divina hoc potest indubitanter." Maino discusses creatio ex aeterno on ff. 96va-97ra.

${ }^{41}$ Magninus de Maineriis, Quaestiones in De substantia orbis, q. VI, Utrum ex nihilo possit aliquid fieri (Firenze, Biblioteca Nazionale, Conv. Soppr. J III 6, f. 97ra): "Sed ego dicam ad quaestionem quod diceret Aristoteles et Commentator eius quod ex nihilo nihil potest fieri."

${ }^{42}$ From the long corpus of questions see for instance this excerpt: Magninus de Maineriis, Quaestiones in De substantia orbis, q. VI, Utrum ex nihilo possit aliquid fieri (Firenze, Biblioteca Nazionale, Conv. Soppr. J III 6, f. 98ra): "Dico quod ad evitandum creationem sufficit quod praexistat aliquid de eo quod producitur; modo quod producitur est compositum; et ideo sufficit quod praexistat aliquid de composito, scilicet materia. Sed ratio concludit quod ad minus forma creabitur, quia nihil praeexistet de forma. Ego possum dicere quod forma non generatur nisi per accidens ut dicunt plurimi compositum autem per se primo. Et ideo dicam quod ad evitandum creationem sufficit quod praeexistat aliquid de composito, scilicet materia."

${ }^{43}$ Magninus de Maineriis, Quaestiones in De substantia orbis, q. VI, Utrum ex nihilo possit aliquid fieri (Firenze, Biblioteca Nazionale, Conv. Soppr. J III 6, f. 98ra: "Credo dicendum quod primum principium non est infiniti vigoris, quia Philosophus non habet plus ponere de primo principio quam possit per motum investigari; sed per motum non potest investigari primum esse infiniti vigoris, nam ad hoc quod virtus aliqua moveat per tempus infinitum sufficit quod sit infinita in essendo et infatigabilis in operando." 
with the above-discussed problem of creation ${ }^{44}$ —according to philosophical argument suitable for this line of investigation.

A large part of Maino's question remains in the exegetic and doctrinal character of Fernand's commentary and is devoted to a discussion of divine causality and God's power. When considering the first principle, which is primarily the separate being, a twofold concept of its infinity can be raised. The infinity of the first principle can be considered either as an infinity of God as (1) finis motus or as (2) an agens motum. If the prime mover is accepted to be active mover (movens active) it has to be of finite force; if, however, it is considered as an end (finis), the prime mover should be described as not having finite or infinite power because power of movement - properly speaking - is something related to separate substances as being active movers, which the prime mover is not. ${ }^{45}$ Nevertheless, Maino rejects this opinion-similarly to Fernand's earlier objections regarding popular misconceptions about the Commentator-and exposes it as a wrong interpretation of Averroes's intention. Maino clarifies that Averroes himself argued in his commentary on Physics VIII that finite and infinite might be considered only in reference to bodies since only bodies have extension and magnitude. Separate intelligences, however, are not inhered in bodies, so they are neither finite nor infinite. Consequently, the same applies - according to Maino's exposition of Averroes - to the prime mover seen as an active mover, i.e., as an efficient cause, but not to the prime mover as a final cause. ${ }^{46}$

${ }^{44}$ On this topic and its relation with divine power and causality, see above p. 196. See also the critical reassessment below, pp. 203-206.

45 Magninus de Maineriis, Quaestiones in De substantia orbis, q. VI, Utrum ex nihilo possit aliquid fieri (Firenze, Biblioteca Nazionale, Conv. Soppr. J III 6, f. 98va): "Et ideo aliter dicitur quod primum principium de quo loquitur principaliter quod est separatum potest considerari: Uno modo ut finis motus; alio modo ut agens motum. Et similiter intelligo de aliis: Si accipiatur ut movens active sic habet vigorem finitum et debet dici finiti vigoris; sed si consideratur ut finis, sic non debet dici vigoris finiti vel infiniti, nam vigor proprie debetur separatis ut moventia active."

46 Magninus de Maineriis, Quaestiones in De substantia orbis, q. VI, Utrum ex nihilo possit aliquid fieri (Firenze, Biblioteca Nazionale, Conv. Soppr. J III 6, f. 98va): "Sed istud est omnino extra intentionem Commentatoris, quia ipse ponit rationem ad probandum propositum, quia finitum et infinitum sunt solum in corporibus, modo certum quod intelligentiae ut moventes sunt non sunt in corporibus, ergo ut sic non habebunt vigorem finitum nec infinitum. Et Commentator loquitur in 8 Physicorum secundum materiam 
In order to elucidate the essence of separate substances, i.e., the movers of the spheres, Maino introduces what he proudly calls his own exposition, which he never heard in Paris. It reads as follows: to any finite power corresponds a finite time proportional to it, and it applies to every amount of time or magnitude; and to infinite power likewise corresponds infinite time and infinite magnitude. Hence, infinite power as such cannot correspond to finite magnitude, and the same applies to movement of infinite velocity. If any separate substance had performed an action of infinite power, it would have happened in no time (in instanti) which will clearly not be possible since the movement must be performed within time. ${ }^{47}$

When he analyzes the distinction between efficient and final causality in the prime mover, Maino refers to the difference between motor separatus

subiectivam, modo certum est quod ibi consideratur primus motor ut movens active et non ut finis, et ideo ut sic loquebatur ibi de primo motore."

${ }^{47}$ Magninus de Maineriis, Quaestiones in De substantia orbis, q. VI, Utrum ex nihilo possit aliquid fieri (Firenze, Biblioteca Nazionale, Conv. Soppr. J III 6, f. 98va): "Et ideo aliter dico cum Commentatore quod virtutes separatae non debent dici finitae nec infinitae in vigore eo modo, supple, quo virtutes in corpore sunt finitae vel infinitae in vigore, nam virtutes corporales sic dicuntur finiti vigoris quod finitati vigoris correspondet finitas temporis et qualis est proportio in vigoribus, eadem est in temporibus mensurantibus et magnitudinibus; et infinitati vigoris correspondet infinitas temporis et magnitudinis. Et per illum modum vult dicere Commentator quod vigor separatorum non est finitus nec infinitus, quia finitati vigoris non correspondet finitas temporis nec est proportio in temporibus quae est in vigoribus. Non ergo possit dici vigoris finiti eo modo quo illa inferiora corporalia, quia tempus durationis earum est infinitum et non finitum, nec possit dici vigoris infiniti eo modo quo ista inferiora dicuntur vigoris infiniti, nam aliquid hic inferius existens habens vigorem infinitum, si esset aliquid tale tempus durationis cuius excederet tempus durationis cuiuslibet alterius finiti vigoris in infinitum. Sed dato quod poneres aliquid separatum infiniti vigoris, tamen tempus durationis eius non excederet tempus durationis alicuius alterius finiti vigoris, quia omnia separata dato quod sunt vigoris finiti per vigorem finitum durant in finitum. Immo si finitum et infinitum eodem modo essent in separatis et corporalibus, sequeretur quod omnia separata essent vigoris infiniti, quia tempus correspondens eorum actionibus esset infinitum et tunc sequeretur quod non moverent sua mobilia indeterminata velocitate quod tamen est falsum, immo si stella adderetur orbi, non moveret orbem nisi cum fatigatione et poena, ut patet 2 Caeli ab Aristotele et Commentatore et illo modo intellexit Commentator quod non debent dici finiti vigoris vel infiniti secundum quod proportionantur finitati temporis et infinitati eius, sed quoniam sint finiti vigoris secundum quod proportionantur velocitati et tarditati motus non intendit Commentator. Et in illa expositione quam numquam audivi declarabatur anima mea et illam expositionem accepi ex dictis Commentatoris in fine 7 Physicorum." 
and motor appropriatus. He writes that - according to some schoolmen - the Commentator, having already introduced his view in the Long Commentary on the Metaphysics XII, makes corrections to it in the De substantia orbis. Nevertheless, as Maino puts it, it does not seem so - on the contrary, in the De substantia orbis Averroes upholds the same view, which is also to be found originally in Aristotle and his De caelo II. ${ }^{48}$ According to Aristotle then, there are entities that attain their perfection and goodness without any action, some attain it with one action, and others with multiple actions. The prime mover, however, attains its goodness and perfection performing no action or movement whatsoever, since it itself is the superior being that does not need anything but itself and, consequently, is unchangeable and immovable. Therefore, it is no prime mover, motor separatus, which actively and directly moves the heavens as an efficient cause, but is its connected mover, motor appropriatus, an intelligence created by the prime mover that moves the heavens immediately and with finite and determined velocity by the desire of prime mover as the universal end (finis) of consecutive spheres. ${ }^{49}$

${ }^{48}$ For respective views in De substantia orbis, see pp. 188-190. See also: Aristotle, De caelo II.12 (292a28-292b15); Averroes, Commentum in De caelo, lib. II, com. 63-64 per totum (ed. Carmody, 2003, pp. 395-396).

49 Magninus de Maineriis, Quaestiones in De substantia orbis, q. VI, Utrum ex nihilo possit aliquid fieri (Firenze, Biblioteca Nazionale, Conv. Soppr. J III 6, f. 98va): "Ad aliam 12 Metaphysicae dicunt aliqui quod Commentator dixit ibi et ideo se corrigit in libello De substantia orbis, tamen non audio Commentatorem negare sic expresse. Ista auctoritas videtur implicare duo difficilia. Primum est quod primum < principium $>$ sit infiniti vigoris nec unquam vidi auctoritatem magis expressam ad hoc probandum. Secundo difficile videtur in auctoritate quod primum principium non moveat primum caelum immediate effective. Ponit enim Commentator motorem appropriatum a quo habet velocitatem terminatam et illa videtur esse intentio Aristotelis et Commentatoris 2 Caeli capitulo de duabus difficilibus quaestionibus. Dicit enim Philosophus quod quaedam sunt quae attingunt suam perfectionem et suum bonum sine actione et intelligere videtur motorem caeli et alia unica actione et alia pluribus actionibus ut ipse dicit. Motor igitur primus attinget suum bonum sine actione aliqua et sic non movebit caelum effective, sed solum in ratione finis et illud videtur velle Aristoteles in 12 Metaphysicae, dicit enim semper quod primum movet ut appetibile et tale movet solum in ratione finis." See also Magninus de Maineriis, Quaestiones in De substantia orbis, q. VI, Utrum ex nihilo possit aliquid fieri (Firenze, Biblioteca Nazionale, Conv. Soppr. J III 6, f. 98vb): “Ad auctoritatem Commentator dicit in 12 quod caelum movere a duplici motore etc. potest dici quod Commentator intellexit de aliis motibus a motu primo quia alii motus habent motorem appropriatum praeter primum a quo habent velocitatem determinatam et a primo habent aeternitatem et si intelligatur de primo motu tunc dicam quod non intellexit Commentator 
Hence, it is allowed to say that the prime mover has a finite force of movement, but only as moving through the second mover, the intelligence of the last sphere. Yet, speaking in absolute terms, it is beyond infinity and finitude.

\section{Anonymous of Erfurt on the De substantia orbis}

In the commentaries analyzed thus far, a unanimity of approach can be easily observed. The adopted solutions read as follows: (1) the prime mover has infinite power in duration; (2) the prime mover, motor separatus, is a final cause of the universe and the most desirable and the noblest being; (3) the mover of the first sphere, motor appropriatus, moves by desiring and thinking the prime mover; (4) The prime mover, a final cause, moves the universe eternally through the second mover, an efficient cause, with a constant and finite force of movement; (5) the idea of creation ex nihilo is unacceptable in the field of philosophy which is a result of denying God's infinite power and its efficient causality.

The third of the discussed commentaries on the De substantia orbis presents what appears to be an utterly different view. Its author-although commenting upon Averroes and often referring to his views affirmativelydoes not share the conclusions reached by the exegetic commentaries of Fernand of Spain and Maino de' Maineri, also reinterpreting some basic tenets to be found in Averroes's works. This anonymous work was written ca. 1362 in the Erfurt milieu where Averroes's commentaries and Averroistic works were held in high esteem. ${ }^{50}$ The commentary consists of expositio ad litteram and quaestiones. The anonymous author refers in his questions

quod habeat duos motores realiter differentes sed voluit dicere quod motor primus consideratus ut efficiens motum erat motor appropriatus sed ut finis erat separatus magis et talis motus primus habet velocitatem determinatam a deo ut movens effective et a primo habet aeternitatem ut finis motus nam quia primum se intelligit in infinitum et se desiderat in infinitum pro tanto movet per tempus infinitum."

50 The question-commentary has been preserved in two manuscripts differing in a number of questions: Kraków, Biblioteka Uniwersytecka, 735, ff. 109ra-116vb (breaks in the middle of q. VII) and Kraków, Biblioteka Uniwersytecka 739, ff. $74 \mathrm{ra}-91 \mathrm{rb}$. The latter manuscript also contains exposition-commentary on ff. $92 \mathrm{ra}-102 \mathrm{vb}, 116 \mathrm{ra}-\mathrm{va}, 103 \mathrm{va}-115 \mathrm{vb}$. For a detailed description of these manuscripts, see Kowalczyk et al., 1993, pp. 229-236, 256-261. For an overview and dating of this commentary, see Kuksewicz, 1986, pp. 28-30. Kuksewicz was also the first to recognize 
to the same problems as Fernand and Maino-God's infinite power, divine causality, and the problem of God's ability to create out of nothing. For the purposes of this presentation, I chose to analyze at length two questions from this commentary, i.e., question VII, Utrum primum principium, scilicet deus, sit infinitus intensive, and question IX, Utrum mundus exivit in esse a deo per modum causae efficientis.

At the beginning of question VII, which deals with the infinite power of God, the Erfurt master refers to Cordovan's authority. He claims that, according to Averroes, the prime mover does not have a finite but infinite power, for God is not connected with a magnitude and exceeds any power. ${ }^{51}$ This statement is followed by the conclusions he is eventually going to reject, i.e., (1) God is infinite in duration; ${ }^{52}$ (2) God is not infinite in power, ${ }^{53}$ (3) God is not infinite in intensive action (which is directly related

this commentary as critical to Averroes. For further literature on the Erfurt milieu, see: Kuksewicz, 1985, pp. V-XXVIII; Kuksewicz, 2007; Lorenz, 1989, pp. 135-139.

51 Anonymus Erfordiensis, Commentum in De substantia orbis, q. VII, Utrum primum principium, scilicet deus, sit infinitus intensive (Kraków, Biblioteka Uniwersytecka 739, f. 83ra; Kraków, Biblioteka Uniwersytecka 735, f. 116ra): “In oppositum est Averroes in textu quia concludit motorem primum non esse potentiae finitae, sed infinitae et ibidem: Nonnulla virtus potest esse separata a magnitudine; sicut est de primo principio. Illud probatur rationibus: Illa virtus quae in infinitum excedit virtutem finitam illa est infinita; primum principium in infinitum excedit quamcumquelibet virtutem finitam; igitur. Maior nota, quia virtus finita intensive potest alteri virtute finitae proportionari. Minor patet, quia deus excedit virtutem lapidis secundum duplum, tripulum et quadrupulum et sic sine statu." Such a curious rendition of Averroes seems to be supported by two intermingled ideas borrowed from the De substantia orbis III and commentary on the Physics, lib. VIII, com. 86. From the former he derives the meaning of infinitum as solely "virtus infinitae actionis aut passionis". From the latter, he borrows the idea of the prime mover as being of infinite action and beyond matter. See: Averroes, De substantia orbis III (ed. Iuntina IX, f. 9rbF-vaG); Averroes, Commentum in Phys., lib. VIII, com. 86 (ed. Iuntina IV, f. 433vbK). See above pp. 185-190.

52 Anonymus Erfordiensis, Commentum in De substantia orbis, q. VII, Utrum primum principium, scilicet deus, sit infinitus intensive (Kraków, Biblioteka Uniwersytecka 739, f. 83rb; Kraków, Biblioteka Uniwersytecka 735, f. 116rb): "Primo, primum principium est infinitum duratione. Hoc probatur: Illud quod est aeternum et incorruptibile est infinitum in duratione; primum principium est huiusmodi; igitur. Maior nota quia aeternitas primi est sua duratio. Minor patet, quia deus ab aeterno fuit et in aeternum erit, tam secundum philosophos quam theologos."

53 Anonymus Erfordiensis, Commentum in De substantia orbis, q. VII, Utrum primum principium, scilicet deus, sit infinitus intensive (Kraków, Biblioteka Uniwersytecka 739, 
to the second conclusion). ${ }^{54}$ He stresses, however, that, notwithstanding the view represented by many philosophers, he will argue for a solution more probable and complete (probabilius et completius), yet contradictory to the three conclusions referred to above. ${ }^{55}$ For instance, he criticizes the view that God is infinite solely in the aspect of time but finite in action. He argues that the first principle's temporal duration is its action, for in God all kinds of action are identical due to the simplicity of its nature. God is therefore infinite both in his action and duration. ${ }^{56}$ When he characterizes the infinity of God, the anonymous author lists four affirmative conclusions, the two first of which could also be found in Averroes. ${ }^{57} \mathrm{He}$ argues that the

f. 83rb; Kraków, Biblioteka Uniwersytecka 735, f. 116rb): "Secunda conclusio: Primum principium non est infinitum in vigore. Hoc probatur, quia si sic, tunc motus posset fieri in instanti. Consequens falsum. Falsitas patet 4 et 6 Physicorum. Consequentia probatur, quia si deus est infiniti vigoris, tunc potest in quemcumque effectum et per consequens potest producere motum subito."

${ }^{54}$ Anonymus Erfordiensis, Commentum in De substantia orbis, q. VII, Utrum primum principium, scilicet deus, sit infinitus intensive (Kraków, Biblioteka Uniwersytecka 739, f. 83rb; Kraków, Biblioteka Uniwersytecka 735, f. 116rb): “Tertia conclusio: Primum principium non est infinitum actione intensive. Illud probatur: Omne agens certae actionis vel potentiae ex opposito distinguitur; sed quia caelum movetur motu finito et per consequens actio est finita."

${ }^{55}$ Anonymus Erfordiensis, Commentum in De substantia orbis, q. VII, Utrum primum principium, scilicet deus, sit infinitus intensive (Kraków, Biblioteka Uniwersytecka 739, f. 83rb; Kraków, Biblioteka Uniwersytecka 735, f. 116rb): "Quamvis ista fuerit virorum bene dicentium secundum hoc, verumtamen probabilius dicetur et completius et arguitur contra haec dicta."

${ }^{56}$ Anonymus Erfordiensis, Commentum in De substantia orbis, q. VII, Utrum primum principium, scilicet deus, sit infinitus intensive (Kraków, Biblioteka Uniwersytecka 739, f. 83rb; Kraków, Biblioteka Uniwersytecka 735, f. 116rb): "Videtur primo, quod conclusiones contradixerunt. Ad probandum: Quia praemittit eo quod duratio primi principii sit sua actio: Hoc patet, quia omnia primo identificantur. Secundo praemittit eo quod duratio primo principii sit sua actio, a principio non distinguantur. Ex hoc arguitur: Haec duratio primi principii est infinita; haec duratio prima est sua actio; igitur sua actio erit infinita et sequitur conclusio praeintenta."

${ }^{57}$ Anonymus Erfordiensis, Commentum in De substantia orbis, q. VII, Utrum primum principium, scilicet deus, sit infinitus intensive (Kraków, Biblioteka Uniwersytecka 739, f. 83va; Kraków, Biblioteka Uniwersytecka 735, f. 116va): "His visis prima conclusio: Primum principium non est infinitum infinitate mobilis. [...] Secunda conclusio quod principium primum non est infinitum infinitate quantitatis. [...] Tertia conclusio: Primum principium infinitum est in perfectione. [...] Est quarta conclusio: Primum principium non est infinitum perfectione dependentis." 
concept of finite-infinite when speaking of infinitas mobilis and inifinitas quantitatis refers to what is divisible, has parts and inheres in the matter. God, however, is simple and remains beyond the matter. This explanation refers to Averroes's argument from commentary on the Physics VIII, referred to above several times. ${ }^{58}$ In the third conclusion, the Erfurt master claims God to be infinite, for it surpasses all beings and thus has infinite perfection. ${ }^{59}$ In the fourth, he argues that God is the only being that is utterly independent and self-reliant. ${ }^{60}$ The third and fourth conclusions go beyond the spectrum of Averroes's investigations and are not to be found in his works.

The consequences of these assumptions are particularly apparent in question IX, where the anonymous author deliberates on the problem of God's power to create as causa efficiens. He argues that God has to be both the efficient and final cause which he derives from the De substantia orbis, interpreting Averroes' position on separate substances as final and efficient causes as referring to the prime mover itself. ${ }^{61}$ Such a rendition justifies the anonymous commentator's claims that God could and can create a human being, a fly, or the whole world without any effort whatsoever. ${ }^{62}$ Afterwards,

58 See above pp. 186, 191-192, 199.

59 Anonymus Erfordiensis, Commentum in De substantia orbis, q. VII, Utrum primum principium, scilicet deus, sit infinitus intensive (Kraków, Biblioteka Uniwersytecka 739, f. 84ra): "Tertia conclusio: Primum principium infinitum est in perfectione. Illa probatur: Illud quod excedit quamlibet perfectionem in infinitum entis hoc est infinitum in perfectione; primum principium est huiusmodi."

${ }^{60}$ Anonymus Erfordiensis, Commentum in De substantia orbis, q. VII, Utrum primum principium, scilicet deus, sit infinitus intensive (Kraków, Biblioteka Uniwersytecka 739, f. 84va): "Est quarta conclusio: Primum principium non est infinitum perfectione dependentis. Illa probatur: Omne dependens est finitae perfectionis; igitur primum non est dependens."

${ }^{61}$ Anonymus Erfordiensis, Commentum in De substantia orbis, q. IX, Utrum mundus exivit in esse a deo per modum causae efficientis (Kraków, Bibilioteka Uniwersytecka 739, f. 87rb): "In oppositum est Averroes in littera dicit enim nihil est efficiens et finis in separatis; sed deus est finis totius mundi; igitur efficiens. Et si sic, habetur intentum. Hoc confirmatur ab hoc quidem ente, id est a deo." See Averroes' original position on pp. 188-190.

${ }^{62}$ Anonymus Erfordiensis, Commentum in De substantia orbis, q. IX, Utrum mundus exivit in esse a deo per modum causae efficientis (Kraków, Bibilioteka Uniwersytecka 739, f. 87rb): "Probatur ratione: Deus potuit et potest omnem hominem producere in esse vel muscam et non est difficilius producere deo totum mundum seu produxisse quoniam talem muscam ex quo non agit cum resistentia et fatigatione." 
the anonymous commentator establishes the terminology he will be using, then he presents views of Aristotle and the Commentator followed by the exposition of the author's own view, critical of Averroes. ${ }^{63}$ Firstly, the Erfurt master explains the attributes of the eternal being using the definitions from Boethius's De consolatione and he defines them as (1) interminabile and (2) immensurabile tempore. ${ }^{64}$ Then the author concludes that this being is necessarily God - he is infinitely perfect (interminabilis perfectionis), so he created the world ex nihilo. ${ }^{65}$ Following this assumption, he discusses the question of God as creating the world de novo without relying on the previously created matter. The world and all that is created is the immediate effect of creation subject to the first principle as the efficient cause (causa efficens). The first principle, as could be already seen in the question on the infinite power of God, is perfect and, consequently, independent. ${ }^{66}$

The central part of the question is the presentation of the thirteen arguments for the eternity of the world. They are listed only to be eventually

63 Anonymus Erfordiensis, Commentum in De substantia orbis, q. IX, Utrum mundus exivit in esse a deo per modum causae efficientis (Kraków, Bibilioteka Uniwersytecka 739, f. 87rb): "In quaestione sic procedam ponendo. Primo motam magistri Conradi de Monte Puellarum; deinde ponendo rationes Commentatoris quae videntur in oppositum sonare contra positionem motam; tertio declarando modum defensandi mundum fuisse de novo productum."

${ }^{64}$ Anonymus Erfordiensis, Commentum in De substantia orbis, q. IX, Utrum mundus exivit in esse a deo per modum causae efficientis (Kraków, Bibilioteka Uniwersytecka 739, f. 87rb): "Circa primam partem est sciendum quod [spat. vac.] aeternitas mundi, videlicet an mundus ab aeterno fuisset, an aeternitas secundum Boethium 5 De consolatione sic diffinitur: 'Est enim interminabilis vitae simul tota perfecta possesio'. Hic duo inuuntur: Primo quod ens aeternum debet esse inteminabile; secundo innuitur quod huiusmodi ens non debet mensurari tempore seu secundum prius et posterius, quare innuitur omnia quae sunt in tempore senescunt et thabescunt, ut dicitur 4 Physicorum tractatu de tempore."

65 Anonymus Erfordiensis, Commentum in De substantia orbis, q. IX, Utrum mundus exivit in esse a deo per modum causae efficientis (Kraków, Bibilioteka Uniwersytecka 739 , f. 87rb): "Deus gloriosus produxit mundum in esse de novo. Hoc probatur, quia est perfectionis non interminabilis. Contradictio, ergo deus <est perfectionis interminabilis et> potuit mundum producere in esse."

${ }^{66}$ Anonymus Erfordiensis, Commentum in De substantia orbis, q. IX, Utrum mundus exivit in esse a deo per modum causae efficientis (Kraków, Bibilioteka Uniwersytecka 739, f. 88ra): "Deus voluntate sua mundum produxit de novo in esse non sub isto $<$ subiecto $>$ praeiacente. Ista probatur mundus seu caelum est effectus dependens a primo; ergo aliquando incepit esse. Consequentia tenet etiam totum omne dependens a deo incepisset esse secundum illum modum producendi." 
disproved one after another. The first states that God is not able to create the world, for it would have to happen ex nihilo, which is impossible. ${ }^{67}$ The anonymous author refutes this position by stating this sort of action to be possible when considering it not accompanied by form or matter, i.e., creation ex nihilo would not be possible if considered as a qualitative change (alteratio) that assumes the prior existence of the subject of change. ${ }^{68}$ Ultimately, he clarifies his view as follows: God created the world ex nihilo by his own will, and, as such, the world is the effect dependent on God as the perfectly independent first principle. He refers then to the independence of the power of God repeatedly and stresses it in question X likewise, where it is explicitly affirmed that the world is not eternal but had a beginning in time for, as it was explained above, it is the effect of creation dependent on the first principle. ${ }^{69}$

To sum up, the conclusions drawn by the author are following: (1) the prime mover has infinite power not only in duration but also in action; (2) the prime mover is the final and efficient cause that does not need any mediation between itself and the created world; (3) the world was created ex nihilo, without any prior matter. All of these assumptions-compared with the two former commentaries - step against the principles commonly assumed in the field of natural philosophy.

67 Anonymus Erfordiensis, Commentum in De substantia orbis, q. IX, Utrum mundus exivit in esse a deo per modum causae efficientis (Kraków, Bibilioteka Uniwersytecka 739, f. 87va): "Primo sic [...] si deus produxisset mundum de novo, sequitur quod deus aliquid extra illum immediate perpetuisset. Consequens falsum, ergo ex quo sequitur falsum. Consequens probatur, quia omne quod fit ex aliquo fit. Consequentia probatur, quia si mundum de novo produxisset, tunc ex nihilo ex quo nihil subiit."

${ }^{68}$ Anonymus Erfordiensis, Commentum in De substantia orbis, q. IX, Utrum mundus exivit in esse a deo per modum causae efficientis (Kraków, Bibilioteka Uniwersytecka 739, f. 88va): "Primo ad primum: Tunc agens effectum produceret ex nihilo etc. Dico aliquid produci ex nihilo est dupliciter: Vel ut dicit carentiam causae efficientis et finis. Sic est falsum. Alio modo ut dicit carentiam materiae et formae, et sic potest concedi. Et sic est de mundi productione. Tu dicis: Ex nihilo nihil fit. Dico quod hoc innuitur de illo quod sit per alterationem [...] et dispositionem iuxta illud, omne illud quod sit per alterationem [...] hoc semper aliquid praerequirit."

69 Anonymus Erfordiensis, Commentum in De substantia orbis, q. X, Utrum mundus fuerit ab aeterno (Kraków, Biblioteka Uniwersytecka 739, f. 89rb): “Ad quaestionem est dupliciter conclusio: Est productus a deo et incepit esse. Probatur ista: Illud quod depensum est ab alio hoc incepit esse, sed mundus est huiusmodi. Praeterea, patet, quia depensum $<$ est $>$ a primo principio." 


\section{Conclusion}

The questions raised in the De substantia orbis provided the opportunity for discussing the problem of God's power and divine causality from various perspectives. In the first two commentaries - composed by Fernand of Spain and Maino de' Maineri-we observed nothing but an endeavor to expound Averroes' views with accuracy, often defending the Commentator against numerous popular misconceptions about his philosophy. ${ }^{70}$ The occasion for commenting upon the De substantia orbis is also a point of departure for seeking the concordance between different places in Averroes's commentaries to propose a possibly uniform view on the problems under investigation. Hence, due to their conceptual framework, these commentaries represent what we introduced at the beginning of this article as an exegetic approach to the De substantia orbis. In the context of this work, the exegetic approach represents, from the vantage point of faith reading, a heterodox and controversial view of Aristotelian physics, scrutinizing problems of the prime mover's nature and divine causality solely and consistently in terms of Averroes's exposition of natural philosophy, relying only on cognition provided by natural reason.

The anonymous commentary from Erfurt enables us to see that the reception of the De substantia orbis and its commentary tradition was far from being uniform. On the contrary, this anonymous work proves that commenting directly on Averroes was not always and necessarily a pretext for schoolmen to develop a heterodox interpretation of Aristotle as seen in the two Parisian commentaries. Despite it being a commentary on Averroes, and despite several, sometimes even affirmative references to the Commentator, in a context so controversial as that discussed here, the doctrinal character of this work remains critical to the Cordovan savant, and its aspirations are not focused on exegesis; on the contrary, the anonymous Erfurt master opts for orthodox solutions to the question of the natural cognition of God's attributes, especially its power, and to the question of divine causality, i.e. to the way God affects the created world. Thus, the anonymous commentary goes far beyond Averroes' perspective in discussing his treatise and uses entirely different reasoning in his investigations. In the case of this work, the Commentator's treaty was utilized to develop the philosophy of nature

\footnotetext{
70 For such misconceptions, see above p. 191 and p. 199.
} 
consistent with the view of the Catholic faith, and it provided the anonymous author with the opportunity to critically reassess some of the crucial tenets of Aristotelian physics. Thus, the conclusions accepted in the third commentary are precisely opposite to those of Fernand or Maino and represent what I labelled as a critical approach to the De substantia orbis. However, what range of diversity there actually is when referring to the practice of commenting upon the De substantia orbis cannot be accurately evaluated here, for we are dealing with numerous, often unedited texts. ${ }^{71}$ The modest intention of this article, however, was to point to some aspects of the medieval Latin reception to Averroes that have thus far only been subject to superficial study. ${ }^{72}$

\section{References}

\section{Primary Sources}

Aegidius Romanus. De materia caeli contra Averroistas. Ed. Venetia, 1500, ff. $85 \mathrm{r}-90 \mathrm{v}$.

Anonymus Erfordiensis. Commentum in De substantia orbis. Kraków, Biblioteka Uniwersytecka 739, ff. 74ra-116vb.

${ }^{71}$ Another example of an ambivalent attitude towards Averroes may be found in the anonymous commentary on the De substantia orbis preserved in manuscript Zwettl, Zisterzienserstift 338, ff. 112ra-127vb. The author of this work is well versed in natural philosophy exegete of the De substantia orbis and calls the opinion of Averroes and Aristotle verior than the opinions of modern commentators when he finds so (see the discussion on the matter of the heavens, f. 112va). At the same time, he very often refers to Averroes as a perversor or perversor confusus, especially when he discusses more controversial issues such as the infinite power of God (see f. 124va-b). Slightly different than the Erfurt commentary discussed here, the Zwettl Anonymous seems to follow Averroes' position very closely, providing convincing exegesis of Averroes' positionsimilar to that of Fernand and Maino, different from that of the Erfurt Anonymous - and lists numerous arguments for a heterodox solution. Yet in the end, he forcefully rejects Averroes' position. I discovered this commentary shortly before finishing this article, hence I did not include its analysis here. For a description of the manuscript Zwettl, Zisterzienserstift, 338, see Ziegler, 1997, pp. 125-130; the author of the catalogue falsely ascribes this commentary to John of Jandun.

72 For some recent studies on medieval Latin commentaries on the De substantia orbis, in a particular reference to Fernand of Spain, Maino de' Maineri, and Walter Burley, see: Fioravanti, 2016; Lamy, 2012a; Lamy, 2012b; Vittorini, 2011. 
Anonymus Zwettlensis. Commentum in De substantia orbis. Zwettl, Zisterzienserstift 338 , ff. $112 \mathrm{ra}-127 \mathrm{vb}$.

Averroes (2003). Commentum in De caelo. In: E. Carmody (ed.), Averrois Cordubensis commentum magnum super libro De celo et mundo Aristotelis. Leuven: Peeters.

Averroes. Commentum in Metaphys. Ed. Iuntina VIII.

Averroes. Commentum in Phys. Ed. Iuntina IV.

Averroes. De substantia orbis. Ed. Iuntina IX, ff. 3ra-11rb.

Fernandus Hispanus. Commentum in De substantia orbis. Vatican, Biblioteca Apostolica, Vat. lat. 845, ff. 272ra-307rb.

Henricus Totting de Oyta. Quaestiones in De substantia orbis. Erfurt, Biblioteca Amploniana $2^{\circ}$ 297, ff. 149ra-158rb.

Hervaeus Natalis. De materia caeli. Ed. Venetia, 1513, ff. 33rb-53va.

Iohannes Aurifaber de Halberstadt. Sophisma de dimensionibus. Leipzig, Universitatsbibliothek 1444, ff. 149va-152va.

Iohannes de Ianduno. Quaestiones in Physicam. Ed. Venetia, 1544.

Magninus de Maineriis. Quaestiones in De anima III. Bologna, Biblioteca Universitaria 1625 , ff. $144 \mathrm{ra}-167 \mathrm{vb}$.

Magninus de Maineriis. Quaestiones in De substantia orbis. Firenze, Biblioteca Nazionale, MS Conv. Soppr. J III 6, ff. 89ra-108va.

Magninus de Maineriis (2016). Quaestiones super De substantia orbis. Ed. G. Fioravanti. In: A. Rodolfi (ed.), "Ratio practica" e "ratio civilis." Studi di etica e politica medievali per Giancarlo Garfagnini (pp. 216-223). Firenze: Edizioni ETS.

\section{Secondary Sources}

Bianchi, L. (1990). Il vescovo e i filosofi. La condanna parigina del 1277 e l'evoluzione dell'aristotelismo scolastico. Bergamo: Lubrina.

Bianchi, L. (1999). Censure et liberté intellectuelle á l'Université de Paris. Paris: Les Belles Lettres. 
Bianchi, L. (2009). Students, Masters, and "Heterodox" Doctrines at the Parisian Faculty of Arts in the 1270s. Recherches de théologie et philosophie médiévales, 79 (1), 75-109.

Digital Averroes Research Environment. Retrieved from: https://dare.uni-koeln.de/ app (5.01.2021).

Ermatinger (1959). Notes on Some Early Fourteenth Century Scholastic Philosophers. Manuscripta, 3 (3), 155-168.

Ermatinger (1976). Maino de' Maineri in His Still Unstudied Role as Philosopher in Early 14th-Century Paris. Manuscripta, 20 (1), 8-9.

Etzkorn, G.J. (1981). John Reading on the Existence and Unicity of God, Efficient and Final Causality. Franciscan Studies, 41 (1), 110-221.

Fioravanti, G. (1966). Boecio de Dacia e la Storiografia sull'Averroismo. Studi Medievali, 7 (1), 283-322.

Fioravanti, G. (2016). Il principium di Maino de' Maineri alle «Quaestiones super De substantia orbis.» In: A. Rodolfi (ed.), "Ratio practica" e "ratio civilis." Studi di etica e politica medievali per Giancarlo Garfagnini (pp. 207-223). Firenze: Edizioni ETS.

Fioravanti, G. (2017). Due Principia di Maino de' Maineri. In: G. Zuccolin (ed.), Summa doctrina et certa experientia. Studi su medicina e filosofia per Chiara Crisciani (pp. 99-135). Firenze: SISMEL-Edizioni del Galluzzo.

Galle, G., Guldentops, G. (2004). Ferrandus Hispanus on Ideas. In: G. Van Riel, C. Macé (eds.), Platonic Ideas and Concept Formation in Ancient and Medieval Thought (pp. 51-80). Leuven: Leuven University Press.

Hoffmann, R. (2001). Der Metaphysikkommentar des Fernandus Hispanus. Mediaevalia Philosophica Polonorum, 34, 95-101.

Hyman, A. (1986). Averroes'De Substantia Orbis. Critical Edition of the Hebrew Text with English Translation and Commentary. Cambridge,MA-Jerusalem: The Medieval Academy of America and the Israel Academy of Sciences and Humanities.

Imbach, R. (1989). Laien in der Philosophie des Mittelalters. Amsterdam: Verlag B.R. Grüner.

Imbach, R. (1991). L'averroisme latin du XIII' ${ }^{\mathrm{e}}$ siècle. In: R. Imbach, A. Maierù (eds.), Gli studi di filosofia medioevale fra otto e novecento. Contributo a un bilancio storiografico (pp. 191-208). Roma: Edizioni di Storia e Letteratura. 
Jung-Palczewska, E. (1997). A Controversy Concerning Motion and God's Infinite Power in Thomas Aquinas and Latin Averroism. Studia Mediewistyczne, 32, $47-57$.

Kowalczyk, M., Kozłowska, A., Markowski, M., Włodek, S., Zwiercan, M. (1993). Catalogus codicum manuscriptorum medii aevi latinorum qui in Bibliotheca Jagellonica Cracoviae asservantur. Volumen Vnumeros continens inde a 668 usque ad 771. Wratislaviae: Institutum Ossolinianum.

Kristeller, P.O. (1977). Iter Italicum: A Finding List of Uncatalogued Or Incompletely Catalogued Humanistic Mss of the Renaissance in Italian and Other Libraries. Vol. 1: Italy. Agrigento to Novara. Leiden: Brill.

Kuksewicz, Z. (1985). Johannis de Janduno "De infinitate vigoris Dei." Edition critique. Studia Mediewistyczne, 24, 77-152.

Kuksewicz, Z. (1986). Un nouveau témoignage de l'averroïsme à Erfurt. Mediaevalia Philosophica Polonorum, 28, 27-32.

Kuksewicz, Z. (1997). Some Remarks on Erfurt Averroists. Studia Mediewistyczne, $32,93-121$.

Kuksewicz, Z. (1999). Polemika między awerroistami paryskimi XIV wieku: Jan z Janduno i Maino z Mediolanu [The Dispute between the 14th-Century Parisian Averroists: John of Jandun and Maino of Milan]. Biuletyn Biblioteki Jagiellońskiej, 49, 31-44.

Kuksewicz, Z. (2006). Maino of Milan. A Fourteenth Century Parisian Averroist. Medioevo, 31, 337-375.

Kuksewicz, Z. (2007). La découverte d'une école averroïste inconnue: Erfurt. In: J.-B. Brenet (ed.), Averroes et les averroïsmes juif et latin (pp. 299-306). Turnhout: Brepols.

Lamy, A. (2012a). La quantité indéterminée de la matière selon Jean de Jandun. Principes et problèmes ontologiques. Revue de métaphysique et de morale, 74 (2), 147-160.

Lamy, A. (2012b). La théorie averroïste des dimensions indéterminées dans le Traité sur la substance de la sphère céleste (livre I, chapitre 2) de Walter Burley. Freiburger Zeitschrift für Philosophie und Theologie, 59 (1), 26-45.

Lerner, M.-P. (1996). Le monde des sphères. Genèse et triomphe d'une représentation cosmique. Paris: Les Belles Lettres.

Libera, A., de (1991). Penser au Moyen Âge. Paris: Editions du Seuil. 
Licata, G. (2019). Problemi della tradizione a stampa del De substantia orbis. Annali della Scuola Normale Superiore di Pisa. Classe di Lettere e Filosofia, 11 (2), 559-580.

Lorenz, S. (1989). Studium Generale Erfordense. Zum Erfurter Schulleben im 13. und 14. Jahrhundert. Stuttgart: Anton Hiersemann.

Maier, A. (1955). Metaphysische hintergrunde der spatscholstischen Naturphilosophie. Roma: Edizioni di Storia e Letteratura.

Marenbon, J. (2012). Ernest Renan and Averroism: The Story of a Misinterpretation. In: A. Akasoy, G. Giglioni (eds.), Renaissance Averroism and Its Aftermath: Arabic Philosophy in Early Modern Europe (pp. 273-284). Springer.

Maurer, A. (1990). John of Jandun and the Divine Causality. In: A. Maurer, Being and Knowing. Studies in Thomas Aquinas and Late Medieval Philosophers (pp. 275-308). Toronto: Pontifical Institute of Mediaeval Studies.

Piaia, G. (1985). Averroisme Politique: Anatomie d'un Mythe Historiographique. In: A. Zimmermann, I. Craemer-Ruegenberg (eds.), Orientalische Kultur und Europäisches Mittelalter (pp. 288-30). Berlin-New York: De Gruyter.

Pinborg, J. (1985). Die Entwicklung der Sprachtheorie im Mittelalter. MünsterKopenhagen: Aschendorff in Verbindung mit dem Verlag Arne Frost-Hansen.

Punta, F., del, Luna, C. (1989). Aegidii Romani Opera Omnia. I. Catalogo dei manoscritti 1/2* (96-151). Italia (Firenze, Padova, Venezia). Firenze: Leo S. Olschki Editore.

Putallaz, X. (1995). Insolente Liberté. Controverses et Condamnations au XIII siècle. Fribourg: Editions Universitaires de Fribourg.

Riedlinger, H. (1967). Introductio Generalis. In: Raimundi Lulli Opera Latina 154155: Opera Parisiensia anno MCCCIX composita (pp. 5-258). Ed. H. Riedlinger. Palmae Maiorcarum.

Schum, W. (1887). Beschreibendes Verzeichniss der Amplonianischen Handschriften-Sammlung zu Erfurt. Berlin: Weidmannsche Buchhandlung.

Steenberghen, F., van (1974). Introduction à l'étude de la philosophie médiévale. Recueil offert à l'auteur par ses collègues, ses étudiants et ses amis. Louvain: Publications universitaires.

Thijssen, J.M.M.H. (1998). Censure and Heresy At the University of Paris, 1200 1400. Philadelphia: University of Pennsylvania Press.

Vittorini, M. (2011). Il commento di Walter Burley al De substantia orbis. Un'edizione. Medioevo, 36, 301-385. 
Weijers, O. (1996). Le travail intellectuel à la Faculté des arts de Paris: textes et maîtres (ca. 1200-1500). 2, Répertoire des noms commençant par $C-F$. Turnhout: Brepols.

Weijers, O. (2001). Le travail intellectuel à la Faculté des arts de Paris: textes et maîtres (ca. 1200-1500). 4, Répertoire des noms commençant par $H$ et J (jusqu'à Johannes C.). Turnhout: Brepols.

Weijers, O. (2005). Le travail intellectuel à la Faculté des arts de Paris: textes et maîtres (ca. 1200-1500). 6, Répertoire des noms commençant par $L-M-N-O$. Turnhout: Brepols.

Weisheipl, J.A. (1965). The Principle Omne quod movetur ab alio movetur in Medieval Physics. Isis, 56 (1), 26-45.

Xiberta, B.F.M. (1924). De Mag. Guidone Terreni, priore generali ordinis nostri, episcopo Maioricensi et Elnensi. Analecta Ordinis Carmelitarum, 5, 113-206.

Xiberta, B.F.M. (1932). Guiu Terrena. Carmelita de Perpinyà. Barcelona: Institució Patxot.

Ziegler, Ch. (1997). Zisterzienserstift Zwettl. Katalog der Handschriften des Mittelalters, Teil IV: Codex 301-424. Zwettl.

Zimmermann, A. (1968). Ein Averroist des späten 13. Jahrhunderts: Ferrandus de Hispania. Archiv für Geschichte der Philosophie, 50 (1-2), 145-164.

Zimmermann, A. (1994). Remarques et questions relatives à l'oeuvre de Ferrand d'Espagne. In: H. Santiago-Otero (ed.), Diálogo filosófico-religioso entre cristianismo, judaísmo e islamismo durante la edad media en la península iberica: Actes du Colloque international de San Lorenzo de El Escorial 23-26 juin 1991 (pp. 213-228). Turnhout: Brepols.

Zimmermann, I. B. (1995). Kommentare zu der Schrift des Averroes „De substantia orbis“ in der Bibliotheca Amploniana. In: A. Speer (ed.), Die Bibliotheca Amploniana. Ihre Bedeutung im Spannungsfeld von Aristotelismus, Nominalismus und Humanismus (pp. 122-126). Berlin-Boston: De Gruyter.

\begin{abstract}
The subject of this article is the Latin reception of Averroes's treatise De substantia orbis, with special regard to the commentary practice in the late Middle Ages. Numerous philosophical problems were taken up in these commentaries following
\end{abstract}


Averroes's lead. The most controversial among them were these concerning divine attributes, i.e., infinite power, efficient and final causality, and, consequently, God's ability to create out of nothing.

Three different commentaries were therefore chosen to exemplify the key differences between the doctrinal approaches of the commentaries on the De substantia orbis. The first two of them-composed by Fernand of Spain and Maino de' Maineri-represent the exegetic approach, adopting and developing Averroes's ideas; the third commentary - composed by an anonymous author in Erfurt around 1362 - represents the critical approach referring to the questions raised in the De substantia orbis in order to propose orthodox solutions being far from these adopted in the treaty by Averroes himself.

The article aims at scrutinizing the problems of infinite power of God and divine causality as they have been taken up by Latin philosophers from the late 13th to the second half of the 14th century by elucidating the key differences between the two lines of inquiry and highlighting the variety of approaches to Averroes's De substantia orbis. 